\title{
Assessment of Positioned Instillation of Contrast Cystography in Children with Recurrent Urinary Tract Infections
}

\author{
Tekrarlayan Idrar yolu Enfeksiyonu olan Çocuklarda Pozisyonel Yerleştirilen Kontrast \\ Sistografinin Değerlendirilmesi
}

\author{
(1) Hülya Nalçacıoğlu1 , (1) Deniz Demirci2, (1) İsmail Dursun33, (1) Numan Baydilli2, (1) Varol Nalçacıoğlu², (1) Sibel Yel3, \\ (D) Funda Baştuğ1, (D) Zübeyde Gündüz33 , (D) Hakan Poyrazoglu33 , (D) Ruhan Düşünsel 3 \\ ${ }^{1}$ Kayseri Training and Research Hospital, Clinic of Pediatric Nephrology, Kayseri, Turkiye \\ 2Erciyes University Faculty of Medicine, Department of Pediatric Urology, Kayseri, Turkiye \\ ${ }^{3}$ Erciyes University Faculty of Medicine, Department of Pediatric Nephrology, Kayseri, Turkiye
}

What's known on the subject? and What does the study add?

Positioned instillation of contrast (PIC) cystogram is used as a diagnostic tool for the examination of vesicoureteral reflux in patients with recurrent febrile urinary tract infections (UTIS) without any signs of reflux on conventional voiding cystourethrography (VCUG). In this current study, we described our pediatric single center experience with PIC cystogram in recurrent UTIs whose reflux is not identified on conventional VCUG. We hope that this study leads to further development and widespread use of PIC cystography in pediatric diagnostic practice as well as to optimize the algorithm for the treatment of children with febrile UTIs to reveal occult VUR.

\begin{abstract}
Objective: Vesicoureteral reflux (VUR) is considered the most important predisposing factor for urinary tract infection (UTI). Renal damage due to VUR, subsequently renal scarring and the possibility of reflux nephropathy warrant early detection of VUR. Our aim was to evaluate the value of positioned instillation of contrast (PIC) cystography in the detection of VUR in children with recurrent UTI and a normal voiding cystourethrography (VCUG).

Materials and Methods: PIC cystography was performed in each child with the indication of recurrent UTI with a normal VCUG between June 2015 and November 2017.

Results: Thirty-four children (32 girls, 2 boys) aged 7 to 17 years (median, 10 years), were examined. Twenty (58.8\%) patients had normal ultrasound and 12 patients (35.3\%) had bilateral scars detected using 99mTc-dimercaptosuccinic acid (DMSA). Thirty-one (91.2\%) patients were shown to have VUR on PIC cystography. Nine (29\%) patients had no renal scar with positive PIC and $3(12 \%)$ patients had scars with negative PIC. Scars were detected in $13(72.2 \%)$ patients with grade I-II VUR, and 4 (30.8\%) with grade III-IV VUR had no scars on DMSA. There was no significant difference between the results of PIC and DMSA renal scan. Twenty-six patients (76.5\%) with PIC-VUR underwent simultaneous endoscopic injections. During the postoperative follow-up with an average of 12 months, 27 patients showed no evidence of febrile UTIs.

Conclusion: Based on our results, PIC cystogram seems to be a good alternative to invasive voiding cystourethrogram in screening children for VUR. Keywords: Recurrent urinary tract infections, Positioned instillation of contrast cystogram, Children, Occult reflux
\end{abstract}

Öz

Amaç: Vezikoüreteral reflü (VUR) idrar yolu enfeksiyonu (IYE) için en önemli predispozan faktördür. VUR'ye bağlı böbrek hasarı, böbrekte skar oluşumu ve reflü nefropatisi olasılığı, VUR'nun tespiti için en önemli gerekçelerdir. Amacımız, voiding sistoüretrografi (VCUG) reflü tespit edilmemiş tekrarlayan idrar yolu enfeksiyonlu (IYE) çocuklarda VUR saptanmasında konumlu kontrast yerleştirme (PIC) sistografinin değerlendirilmesidir.

Gereç ve Yöntem: Haziran 2015 - Kasım 2017 tarihleri arasında VCUG'de reflü tespit edilmemiş tekrarlayan iYE'li çocuklara PIC sistografi yapıldı. Bulgular: Otuz dört çocuk, yaşları 7-17 arasında değişen (yaşları ortanca, 10 yaş) 32'si kız olan çocuklar incelendi. Yirmi (\%58,8) hastada normal US,

Correspondence: Hülya Nalçacıoğlu MD, Kayseri Training and Research Hospital, Clinic of Pediatric Nephrology, Kayseri, Turkiye Phone: +90 5335674989 E-mail: hulyanalcacoglu@hotmail.com ORCID-ID: orcid.org/0000-0002-0686-9714

Received: 18.11 .2019

Accepted: 20.02 .2020

Cite this article as: Nalçacıoğlu H, Demirci D, Dursun İ, Baydilli N, Nalçacıoğlu V, Yel S, Baştuğ F, Gündüz Z. Assessment of Positioned Instillation of Contrast Cystography in Children with Recurrent Urinary Tract Infections. J Urol Surg 2020;7(1):58-63.

๑Copyright 2020 by the Association of Urological Surgery / Journal of Urological Surgery published by Galenos Publishing House. 
12 hastada $(\% 35,3)$ 99m-Tc-dimerkaptosüksinik asit (DMSA) kullanılarak iki taraflı skar tespit edildi. Otuz bir $(\% 91,2)$ hastanın PIC sistografisinde VUR olduğu görüldü. Dokuz (\%29) hastada PIC pozitif, renal skar yoktu ve 3 (\%12) hastada negatif PIC ile skar vardı. DMSA'da grade I-II VUR'li 13 $(\% 72,2)$ hastada ve grade III-IV VUR'lu 4 hastada $(\% 30,8)$ skar saptanmadı. PIC sistografide reflü ile DMSA'da skar arasında anlamlı ilişki bulunmadı. PIC-VUR'u olan 25 hastaya $(\% 76,5)$ eş zamanlı endoskopik enjeksiyon yapıldı. Postoperatif dönemde ortalama 12 ay takipte olan 27 hastada ateşli iYE tekrarlamadı.

Sonuç: Elde ettiğimiz sonuçlara göre, PIC sistogram VCUG'de reflü tespit edilmemiş tekrarlayan iYE'li çocuklarda VUR saptanmasında alternatif bir tanı aracı olarak kullanılması yararlı görülmektedir.

Anahtar Kelimeler: Rekürren üriner sistem enfeksiyonları, Konumlu kontrast yerleştirme sistogramı, Çocuklar, Gizli reflü

\section{Introduction}

Vesicoureteral reflux (VUR) is considered a common predisposing factor for urinary tract infections (UTIs) with an incidence of $25-40 \%$ in children $(1,2,3)$. Recurrent UTIs associated with VUR can lead to reflux nephropathy, a principal cause of end-stage renal disease in children $(4,5)$. Therefore, early detection and timely treatment of VUR is important in reducing the risk of permanent renal damage.

Voiding cystourethrography (VCUG) is the most widely used fluoroscopic technique in most clinics to confirm VUR as an initial evaluation of children with febrile or recurrent UTIs. However, technique-related and patient preparation-related variables may affect the reliability and accuracy of voiding cystourethrogram (VCUG). Many variables such as different types and sizes of catheters, rate of bladder filling, concentration of contrast agents or intermittent nature of VUR contribute to this problem $(2,6,7,8,9,10)$.

Rubenstein et al. (11) were the first to introduce positioned instillation of contrast (PIC) cystogram which is a new diagnostic tool for detecting VUR in patients with recurrent febrile UTIs despite a normal VCUG. The main advantage of PIC cystography is subureteric injection at the same session when occult VUR is detected. Although there are limited reports on PIC cystogram, the incidence rate of febrile UTI is lowered significantly by treatment of VUR identified by PIC cystography $(12,13,14)$

The aim of our study was to evaluate the value of PIC cystography in the detection of VUR in children with recurrent UTIs all of whom had negative VCUG findings.

\section{Materials and Methods}

We retrospectively reviewed data of 34 pediatric patients who underwent PIC cystography between June 2015 and November 2017. PIC cystography is performed on each child with an indication of recurrent UTI with negative VCUG. This study was approved by the Erciyes University Faculty of Medicine, Institutional Review Board and Ethics Committee (project no.: 2017/543). The patients' parents or legal guardians gave consent for the use of their data for research purposes.
The term "recurrent UTI was defined as more than one episode of pyelonephritis, or one episode of pyelonephritis plus at least one episode of cystitis, or at least three episode of cystitis. All patients were admitted or referred for the evaluation of recurrent UTI and imaging data including renal ultrasonography (US), VCUG, and Tc-99m-dimercaptosuccinic (DMSA) acid renal scintigraphy scans were analyzed in detail upon admission. Exclusion criteria were as follows: presence of anatomic abnormalities such as duplex systems/posterior urethral valves or bladder problems including neurogenic bladder. Lower urinary tract dysfunction (LUTD) was defined by clinical findings, including urgency, urge incontinence, enuresis, hesitancy, intermittent voiding, and weak stream. Children with abnormal voiding patterns were assessed and managed without urodynamic test prior to PIC cystography. Renal scars were evaluated using DMSA based on the criteria of Goldraich et al. (15). A DMSA scan was performed 3-6 months after infection was diagnosed.

Once the bladder was emptied, PIC cystography was performed by using a $9.5 \mathrm{~F}$ or $11 \mathrm{~F}$ pediatric cystoscope with the patient in the dorsal lithotomy position during endoscopy. The cystoscope beak was placed close to the ureteral orifice and the ureteral orifices were identified and evaluated for their trigonal appearance (patulous or not).

Contrast agent was placed at a height of 1 meter above the level of the bladder and flowed toward the orifice via the irrigation port of the cystoscope while the fluoroscopy was performed to evaluate VUR. The bladder was emptied after the procedure was completed. All patients were on antibacterial prophylaxis and had negative culture at the time of the procedure. The grade of PIC-VUR was described by adapting the system of the international reflux classification (16).

If VUR was detected, endoscopic treatment was performed in the same session, surgical reimplantation was performed later. Postoperative follow-up evaluation was done at 1 month with renal and bladder US and urinalysis and culture when indicated. Antimicrobial prophylaxis was continued at this time. Success was defined as having no further febrile UTIs. VCUG and DMSA scans were not performed after antireflux treatment.

For each patient, data were recorded as outlined below. 
(a) Demographic and clinical information; (b) imaging data including renal US, VCUG, and DMSA scan; (c) follow-up data including antimicrobial prophylaxis and the presence of recurrent UTIs. The clinical outcome focused on postoperative febrile UTIs.

\section{Statistical Analysis}

All statistical calculations were made using the Statistical Package for the Social Sciences 22.0 (SPSS IBM Corp, Armonk, New York, USA). The characteristics of the patients were determined using descriptive statistics. Results are given as median (minimum-maximum) or proportion. Categorical variables were evaluated using the chi-square test. Statistical significance was accepted as $p<0.05$.

\section{Results}

Thirty-four children (32 girls and 2 boys) aged 7-17 years (median: 10 years) were identified retrospectively. Twenty-one (61.8\%) patients had a history of febrile, 13 patients had afebrile recurrent UTIs. Demographic and clinical data of patients are summarized in Table 1.

Renal US was normal in 20 children and abnormal (hydronephrosis) in 14. The DMSA renal scan was normal in nine patients and abnormal in 25. Unilateral and bilateral renal scarring was confirmed in $13(38.2 \%)$ and $12(35.3 \%)$ patients, respectively. Thirty-one of the 34 (91.2\%) patients demonstrated reflux on PIC cystogram; PIC-VUR was unilateral in 10 patients and bilateral in 21 patients. Among these patients, 18 had grade I-II VUR and 13 had grade III-IV VUR. Nine patients (29\%) with positive PIC had no renal scar, and $3(12 \%)$ patients with negative PIC had scars. Scars were detected in 13 (72.2\%) patients with grade I-II VUR, and 4 (30.8\%) patients with grade III-IV VUR had no scar on DMSA. There was no significant difference between the results of PIC and DMSA renal scan. 10 of the 34 patients who presented with febrile UTIs had dysfunctional voiding.

Twenty-six (76.5\%) of the 31 patients with PIC-VUR underwent simultaneous endoscopic injection of a bulking agent, dextranomer/hyaluronic acid copolymer. Ureteroneocystostomy was performed in $4(11.8 \%)$ patients. One patient, who had grade I PIC-VUR with no scars on DMSA, did not undergo antireflux surgery. Six patients who had abnormal voiding patterns and managed for LUTD, had subsequent febrile UTIs in the followup period and PIC-VUR was detected. 2 patients who had grade I-II and 4 with grade III-IV VUR underwent endoscopic therapy.

The postoperative follow-up interval was from 5 to 22 months with an average of 12 months. During this time, 27 of the 34 patients were on follow-up. After PIC-VUR treatment, 27 patients showed no evidence of febrile UTIs. Seven of 27 patients experienced afebrile UTIs. All the 7 patients were girls (mean age:
$11.14 \pm 3.28$ years) and 6 of the 7 patients demonstrated PICVUR; 2 patients had grade I-II VUR and 4 had grade III-IV VUR. There were no repeat VCUG and DMSA scans after endoscopic therapy because the infections were not febrile. The 7 female patients demonstrated LUTD despite pelvic floor therapy and behavioural interventions, their afebrile UTIs persisted.

No significant association was found between PIC cystography results and the frequency of UTI, kidney US findings, and DMSA scans ( $p=0.289, p=0.773$ and $p=0.276$, respectively). In contrast, a significant association was found between the PIC results and gender $(p=0.034)$. PIC cystogram did not identify VUR in 3 patients $(8.8 \%)$. Due to few number of patients with negative

Table 1. Clinical characteristics of children underwent PIC cystography with recurrent urinary tract infections

\begin{tabular}{|c|c|}
\hline Variables & $\begin{array}{l}\text { Study population } \\
(n=34)\end{array}$ \\
\hline Age (years) (mean \pm SD) & $10.19 \pm 2.64$ \\
\hline \multicolumn{2}{|l|}{ Gender $(n, \%)$} \\
\hline - Female & 32 (94.1) \\
\hline - Male & $2(5.9)$ \\
\hline \multicolumn{2}{|l|}{ UTIs (n, \%) } \\
\hline - Febrile & $21(61.8)$ \\
\hline - Afebrile & $13(38.2)$ \\
\hline $\begin{array}{l}\text { Dysfunctional voiding (on medical history) } \\
(n, \%)\end{array}$ & $10(29.4)$ \\
\hline \multicolumn{2}{|l|}{ US findings $\mathrm{n}(\%)$} \\
\hline - Normal & $20(58.8)$ \\
\hline - Abnormal (hydronephrosis) & $14(41.2)$ \\
\hline \multicolumn{2}{|l|}{ DMSA Scan Findings $(n, \%)$} \\
\hline - Unilateral scar & $13(38.2)$ \\
\hline - Bilateral scars & $12(35.3)$ \\
\hline \multicolumn{2}{|l|}{ PIC-VUR (n, \%) } \\
\hline - No VUR & $3(8.8)$ \\
\hline - grade I-II VUR & $18(52.9)$ \\
\hline - grade III-IV VUR & 13 (38.2) \\
\hline \multicolumn{2}{|l|}{ Intervention $(\mathrm{n}, \%)$} \\
\hline - Endoscopic & $26(76.5)$ \\
\hline - Open reimplantation & $4(11.8)$ \\
\hline - Medical therapy & $4(11.8)$ \\
\hline Clinical follow-up (months) & $\begin{array}{l}12.62 \pm 5.43 \\
(5-22) \text { (median) }\end{array}$ \\
\hline \multicolumn{2}{|l|}{ UTIs after surgery $(n, \%)$} \\
\hline - None & $27(79.4)$ \\
\hline - Febrile & 0 \\
\hline $\begin{array}{l}\text { - Afebrile } \\
\text { (all of them performed by endoscopic therapy) }\end{array}$ & $7(20.5)$ \\
\hline
\end{tabular}


PIC cystogram results, we cannot make a firm conclusion that PIC cystogram is alternative to VCUG.

\section{Discussion}

VCUG is the most widespread used method as the first modality for the detection of VUR in children $(1,2,3,4)$. However, the biggest challenges physicians face in clinical practice is managing children who had recurrent febrile UTIs with normal VCUG findings. In our study, we focused on the predictive value of showing occult reflux with PIC cystogram and the clinical its effect on recurrent UTIs in patients considered without VUR using standard imaging techniques. We found that 31 of the $34(91.2 \%)$ patients had significant degrees of reflux detected using PIC cystography and the episodes of febrile UTIs were not repeated during follow-up; in some patients there was a decrease in non-febrile UTIs. Although no consensus is available regarding the role of PIC cystogram in children with recurrent UTIs, the findings reported in our study are strikingly similar to those reported previously $(11,12,13,14,17,18,19,20,21,22,23)$.

In the first report by Rubenstein et al. (11), the authors state that PIC cystogram was performed in 30 children with recurrent febrile UTI and normal VCUG, and VUR was detected in all of these children with PIC cystogram. They also no VUR in the control group. During the postoperative 8-months follow-up, none of the patients had recurrent febrile UTIs, similar to that reported by our study. In a study of 39 patients with recurrent febrile UTIs from four centers, PIC-VUR was found in $82 \%$ of the patients (12). Tareen et al. (17) reported that patients with recurrent febrile UTIs without VUR on VCUG should underwent PIC cystogram. Based on these studies, PIC cystogram appeared to be a promising method but, despite high sensitivity, it proved to be less practicable than VCUG.

An important point is to further evaluate whether PIC-positive reflux is truly clinically significant or not. Following a review of these initial studies, a multi-institutional study was performed to evaluate the clinical outcome of postoperative followup of PIC-VUR in 118 patients, focusing on the incidence of postoperative febrile UTIs. The authors showed that the episodes of febrile UTIs was significantly reduced after treatment (13). Another study found a relationship between PIC-VUR grades and severity of renal scarring on DMSA (21). Tareen et al. (17) stated that PIC cystography should be the next step in patients who had a second UTI and had signs of scarring in DMSA and who had no VUR on VCUG. Recently, Haberal et al. (14) from Turkiye examined 198 patients who underwent PIC cystography and reported a reflux rate of 58.3\% in patients with UTIs. The authors concluded that PIC was an effective diagnostic method for revealing occult VUR. In addition, they found that 37.5\% of the unscarred renal units had VUR. They found no significant difference between the results of PIC-VUR and renal scarring on DMSA, in contrast to the findings of Tareen et al. (17). This result is compatible with our findings. Given that, in our cohort, 9 (29\%) patients with positive PIC had no renal scars and $3(12 \%)$ patients with negative PIC had scars. Among these patients, 18 had grade I-II VUR and 13 had grade III-IV VUR. Scars were detected in $13(72.2 \%)$ patients with grade I-IIVUR, and $4(30.8 \%)$ patients with grade III-IV VUR had no scars on DMSA. We found no statistically significant relationship between the presence of scar in DMSA and PIC-VUR. The most important question is whether we should perform PIC cystograms in patients with recurrent infections in whom reflux cannot be shown and who have no scars on DMSA. In view of the literature, VUR can be seen independent of renal scarring $(14,17)$. Patients with PICVUR without renal scarring may not be at risk for renal damage, but they may benefit clinically when a causative factor can be treated by reducing or eliminating future febrile infections.

Haberal et al. (14) found that the infection-free rate in the follow-up was slightly higher in the patients with PIC-VUR, but it was not significantly different from patients who were PIC-negative. They emphasized that the clinical benefit of PIC cystography is not yet clear despite its diagnostic advantage of detecting occult VUR in patients with febrile UTI. In a study of 42 patients with recurrent febrile UTIs from Turkiye, the infection-free rate was found as $80.5 \%$ after PIC cystography and concurrent subureteric injection (22). In our cohort, 31 patients demonstrated PIC-VUR and 30 of the 31 patients were treated via endoscopic injection or ureteral reimplantation; none of them had recurrent febrile UTIs during the follow-up. Despite tha curve of febrile UTIs cured, seven female patients with lower urinary tract dysfunction experienced afebrile UTIs during the follow-up. It also appeared that UTIs in girls were more often associated with dysfunctional voiding. The initial DMSA scan was normal in all THE seven patients; therefore, neither DMSA nor VCUG were repeated. Our patients who had LUTD still have higher rates of recurrent UTls compared with those without LUTD at baseline. The results highlight that there appeared to be a stronger association between VUR and recurrent UTIs in children with LUTD. Although VUR is associated with the risk of recurrent UTI and renal scarring, there has been increased appreciation of other factors, such as bladder and bowel dysfunction, which is an important contributor to the recurrence of UTI, VUR persistence and renal scarring (23). Despite pelvic floor therapy and behavioural interventions, recurrent afebrile UTIs were still present. It may be assumed that LUTD in these patients was the result of an incompetent vesicoureteral junction.

\section{Study Limitations}

This study has a number of limitations. As a retrospective study with a relatively small sample size, it lacks the statistical power required to reach firm conclusions on the superiority of 
any VUR assessment technique. Patients with reflux on VCUG examination were not included in this study, which makes it difficult to interpret subgroup findings of PIC cystography. In this study, we found that PIC-VUR was demonstrable in most cases of recurrent febrile UTIs with normal standard VCUG findings. Despite its advance in determination VUR, we could not state that PIC cystogram is an alternative method to VCUG without insufficient PIC-negative results. Another important limitation is that the PIC process requires general anesthesia. However, it should be stated here that this method is valuable in that it permits examination of the urethra, urinary bladder, and ureteral orifices, and simultaneously allows for subureteric injection for the treatment in patients with PIC-VUR.

\section{Conclusion}

In conclusion, our study shows that PIC cystography may be used as a diagnostic method for predicting VUR in children with recurrent febrile UTIs when VCUG is normal. In addition, after the diagnosis of occult reflux, simultaneous subureteric injection provided the cessation of febrile UTI and decreased the rate of afebrile UTIs in some of our patients. For this reason, the main advantage of PIC cystography is both showing occult reflux and allowing for subureteric injection in patients with PIC-VUR at the same session.

We recommend PIC cystography in children who had recurrent febrile UTI with no VUR on VCUG and scars in DMSA. We hope that this study leads to further development and widespread use of PIC cystography in pediatric diagnostic practice as well as to optimize the algorithm for the treatment of children with febrile UTIs to reveal occult VUR.

\section{Ethics}

Ethics Committee Approval: This study was approved by the Erciyes University Faculty of Medicine Institutional Review Board and Ethics Committee (project no.: 2017/543).

Informed Consent: The patient's parents or legal guardians gave consent to use their data for research purposes.

Peer-review: Externally peer-reviewed.

\section{Authorship Contributions}

Concept: H.N., D.D, I.D Design: H.N., N.B., Data Collection and/or Processing: D.D., N.B., V.N., S.Y., F.B., Analysis and/or Interpretation: H.N., Z.G., H.P., R.D., Literature Research: H.N., N.B., Writing: H.N.

Conflict of Interest: The authors declare no conflicts of interest.

Financial Disclosure: The authors declare that they have no relevant financial.

\section{References}

1. Bell LE, Mattoo TK. Update on childhood urinary tract infection and vesicoureteral reflux. Semin Nephrol 2009;29:349-359.

2. Lim R. Vesicoureteral reflux and urinary tract infection: evolving practices and current controversies in pediatric imaging. Am J Roentgenol 2009;192:1197-1208.

3. Mahyar A, Ayazi P, Tarlan S, Moshiri A, Hamidfar M, Barikani A. When is the best time for voiding cystourethrogram in urinary tract infection of children? Acta Med Iran 2012;50:468-472.

4. Belman $A B$. A perspective on vesicoureteral reflux. Urol Clin North Am $1995 ; 22: 139-150$.

5. Hellerstein S. Urinary tract infections. Old and new concepts. Pediatr Clin North Am 1995;42:1433-1457.

6. Darge $\mathrm{K}$, Riedmiller $\mathrm{H}$. Current status of vesicoureteral reflux diagnosis. World J Urol 2004;22:88-95.

7. Dalirani R, Mahyar A, Sharifian M, Mohkam M, Esfandiar N, Ghehsareh Ardestani $A$. The value of direct radionuclide cystography in the detection of vesicoureteral reflux in children with normal voiding cystourethrography. Pediatr Nephrol 2014;29:2341-2345.

8. Lee RS, Diamond DA, Chow JS. Applying the ALARA concept to the evaluation of vesicoureteric reflux. Pediatr Radiol 2006;36:185-191.

9. Doganis D, Siafas K, Mavrikou M, Issaris G, Martirosova A, Perperidis G, Konstantopoulos A, Sinaniotis K. Does early treatment of urinary tract infection prevent renal damage? Pediatrics 2007;120:922-928.

10. Sükan A, Bayazit AK, Kibar M, Noyan A, Soyupak S, Yapar Z, Anarat A. Comparison of direct radionuclide cystography and voiding direct cystography in the detection of vesicoureteral reflux. Ann Nucl Med 2003;17:549-553.

11. Rubenstein JN, Maizels M, Kim SC, Houston JT. The PIC cystogram: a novel approach to indentify "occult" vesicoureteral reflux in children with febrile urinary tract infections. J Urol 2003;169:2339-2343.

12. Edmonson JD, Maizels M, Alpert SA. Kirsch AJ, Hanna MK, Weiser AC, Caione $P$, Kaplan WE, Cheng EY, Houston JT. Multi-instutitional experience with PIC cystography-incidence of occult vesicoureteral reflux in children with febrile urinary tract infections. Urology 2006;67:608-611.

13. Hagerty J, Maizels M, Kirsch A. Liu D, Afshar K, Bukowski T, Caione P, Homsy Y, Meyer T, Kaplan W; PIC Cystography Group. Treatment of occult reflux lowers the incidence rate of pediatric febrile urinary tract infection. Urology 2008;72:72-76.

14. Haberal HB, Çıtamak B, Altan M, Bozacı AC, Ceylan T, Doğan HS, Tekgül S Positioning the Instillation of Contrast Cystography: Does It Provide Any Clinical Benefit? Urology 2018;112:164-168.

15. Goldraich IH, Goldraich NP, Ramos OL. Classification of reflux nephropathy according to findings at DMSA renal scan. Eur J Paediatr 1983;140:212-218.

16. Lebowitz RL, Olbing $H$, Parkkulainen KV, Smellie JM, Tamminen-Möbius TE. International system of radiographic grading of vesicoureteric reflux. Pediatr Radiol 1985;15:105-109.

17. Tareen BU, Bui D, McMahon DR, Nasrallah PF. Role of positional instillation of contrast cystography in the algorithm for evaluating children with confirmed pyelonephritis. Urology 2006;67:1055-1057.

18. Navai N, Halperin W, Maizels $M$, Yerkes EB, Hagerty J, Kaplan WE. Demonstrating vesicoureteral reflux by positioning the instillation of contrast is a physiological test by manometry. J Urol 2008;179:203.

19. Pinto KJ, Pugach J, Saalfield J. Lack of usefulness of positioned instillation of contrast cystogram after injection of dextranomer/hyaluronic acid. J Urol 2006;176:2654-2656

20. Palmer LS. The role of intraoperative cystography following the injection of dextranomer/hyaluronic acid copolymer. J Urol 2008;179:1118-1121. 
21. Berger $C$, Becker $T$, Koen $M$, Zeino M, Fitz F, Beheshti M, Wolf-Kohlmeier I, Haim S, Riccabona M. Positioning irrigation of contrast cystography for diagnosis of occult vesicoureteric reflux: association with technetium-99m dimercaptosuccinic acid scans. J Pediatr Urol 2013;9:846-850.

22. Karadeniz-Cerit K, Thomas DT, Ergun R, Yıldız N, Alpay H, Inanir S, Dağlı ET, Tuğtepe H. Positional installation of contrast (PIC) and Redo-PIC cystography for diagnosis of occult vesicoureteral reflux. Turk J Pediatr 2018;60:180-187.

23. Avlan D, Gündoğdu G, Taşkınlar H, Delibaş A, Naycı A. Relationships among vesicoureteric reflux, urinary tract infection and renal injury in children with non-neurogenic lower urinary tract dysfunction. J Pediatr Urol $2011 ; 7: 612-615$ 